\title{
TINGKAT PARTISIPASI MASYARAKAT DALAM PEMILIHAN KEPALA DESA SEMUNTAI PADA TAHUN 2014 SEBAGAI IMPLEMENTASI UNDANG-UNDANG NOMOR 6 TAHUN 2014
}

\author{
Septha Suseka, Salim Hidayanto \\ STKIP Persada Khatulistiwa Sintang, Jl. Pertamina-Sengkuang-Sintang \\ Email:cekgupapakebenaran@gmail.com, salimhidayanto140@gmail.com
}

\begin{abstract}
The title of this research is "Community Participation Level in Selection of Semuntai Village Head in 2014 as Implementation of Law Number 6 of 2014". The reason the researchers raised this title to know the level of political participation of Semuntai Village Sepauk Subdistrict Sintang District in 2014 and what factors that encourage and inhibiting the community to participate in the election of the Village Head Semuntai Sepauk Subdistrict Sintang District in 2014. The purpose of this study to describes the participation of the community in the election of the Village Head of Semuntai, to describe the supporting factors and inhibiting the community to participate in the election of Head of Semuntai Village in 2014. The research method used in this study is descriptive qualitative and case study research. Data collection techniques used observation techniques, interviews, and documentation. The results of this study indicate that: 1) the participation of the community in the election of the Village Head of Semuntai in 2014 is still low, 2) the supporting factors of the community to participate in the election of the village head of Semuntai is to make the village self-reliant, advanced and prosperous, the importance of using the right to vote so as to prefer apathy, the lack of public confidence in the candidate for the village head.
\end{abstract}

Keywords: Political Participation, Society and Village Head Election. 


\begin{abstract}
Abstrak
Judul penelitian ini adalah "Tingkat Partisipasi Masyarakat dalam Pemilihan Kepala Desa Semuntai pada tahun 2014 sebagai Implementasi Undang-undang Nomor 6 tahun 2014". Alasan peneliti mengangkat judul ini untuk mengetahui tingkat partisipasi politik masyarakat Desa Semuntai Kecamatan Sepauk Kabupaten Sintang pada tahun 2014, faktor pendorong dan penghambat masyarakat untuk berpartisipasi dalam pemilihan kepala Desa Semuntai Kecamatan Sepauk Kabupaten Sintang tahun 2014. Tujuan dalam penelitian ini untuk mendeskripsikan partisipasi masyarakat dalam pemilihan Kepala Desa Semuntai, untuk mendeskripsikan faktor pendukung dan penghambat masyarakat berpartisipasi pada pemilihan Kepala Desa Semuntai tahun 2014. Metode yang digunakan deskriptif kualitatif dan bentuk penelitian studi kasus. Teknik pengumpulan data menggunakan teknik observasi, wawancara, dan dokumentasi. Hasil penelitian ini menunjukan bahwa: 1) partisipasi masyarakat dalam pemilihan Kepala Desa Semuntai pada tahun 2014 masih rendah, 2) faktor pendukung masyarakat untuk berpartisipasi dalam pemilihan Kepala Desa Semuntai yaitu ingin menjadikan Desa yang mandiri, maju dan sejahtera, faktor penghambat kurangnya pemahaman pemilih terhadap pentingnya menggunakan hak pilih sehingga lebih memilih apatis, kurangnya kepercayaan masyarakat terhadap calon Kepala Desa.
\end{abstract}

Kata Kunci: Partisipasi Politik, Masyarakat dan Pemilihan Kepala Desa. 


\section{A. Pendahuluan}

Pemerintah Desa dipimpin oleh seorang Kepala Desa yang dipilih masyarakat setempat yang sudah mempunyai hak memilih. Selanjutnya syarat dan tata cara pemilihan kepala desa yang berpedoman pada Peraturan Pemerintah Nomor 72 Tahun 2005 tentang Desa, Undang-undang Nomor 15 tahun 2011 tentang penyelenggaraan pemilihan umum serta Undang-undang Nomor 6 tahun 2014 tentang desa. Pemilihan kepala desa tidak terlepas dari partisipasi politik masyarakat desa. Partisipasi politik masyarakat desa akan berjalan dengan lancar apabila ada perilaku politik dari masyarakat desa dan sosialisasi politik serta komunikasipolitik yang baik dari para bakal calon kepala desa mengenai visi dan misi atau program kerja yang akan dilaksanakan.

Pemilihan kepala desa telah dilaksanakan pada tanggal 18 Maret 2014 di Desa Semuntai Kecamatan Sepauk Kabupaten Sintang. Pemilihan tersebut sama hal dengan pejabat yang tingkatannya lebih tinggi, baik dalam bidang eksekutif maupun legeslatif. Pemilihan ini merupakan kegiatan yang di nantikan oleh masyarakat setempat guna menentukan siapa calon orang nomor satu di desanya untuk dapat memimpin dan membawa perubahan yang lebih baik bagi kemajuan desa.
Pemilihan Kepala
merupakan salah satu contoh partisipasi politik masyarakat dalam memberikan hak suaranya. Saat pemilihan Kepala Desa Semuntai tahun 2014, masyarakyat yang memiliki kesadaran berpartisipasi merupakan langkah awal menuju lajur demokrasi yang benar dan tepat.Berdasarkan Undang-undang No 6 Tahun 2014 Pasal (34) ayat (1) Kepala Desa dipilih langsung oleh penduduk Desa.

Supaya masyarakat dapat mengindahkan pesta pemilihan Kepala Desa dengan damai dan jujur perlu menggunakan instrumeninstrumen politik yang mengajak mereka ikut serta dalam pemilihan Kepala Desa. Adapun beberapa instrumen politik yang dapat digunakan berupa sepanduk, baliho dan lain-lain. Dengan adanya instrumen tersebut diharapkan antusias masyarakat akan bertambah. Juliansyah (2013 : 199) mengemukakan bahwa kebijakan politik nasional dengan melibatkan instrumen-instrumen politik agar memiliki semangat untuk membangun jiwa dan keinginan bersama (spirit and political will). Keterlibatan rakyat berpartisipasi dalam bidang politik bersifat penting sebab hal tersebut menjadi bagian yang tidak terpisahkan dengan konsep keadilan sosial.

Berdasarkan hasil wawancara pada tanggal 17 Nopember 2017 antara penulis dengan 2 orang 
masyarakat yang menjadi informan berprofesi sebagai petani di Dusun Belungai Desa Semuntai Kecamatan Sepauk Kabupaten Sintang, diperoleh informasi bahwa partisipasi masyarakat dalam pemilihan Kepala Desa Semuntai pada tahun 2014 sangat rendah.Mereka mengatakan pada saat itu tidak ikut memilih karena tidak bisa meninggalkan pekerjannya. Pada waktu pemilihan mereka lebih memilih bekerja diladang atau menyadap karet dikebun. Mereka beranggapan bahwa pergi keladang dan menyadap karet lebih penting dari pada memilih kepala desa. Hal tersebut menunjukan bahwa dalam kehidupan masyarakat di Desa Semuntai sudah mulai menghilangkan partisipasi politiknya.

Hilangnya partisispasi politik masyarakat dapat memberikan dampak yang buruk dalam keberlangsungan kehidupan berdemokrasi. Oleh karena itu, partisipasi perlu ditingkatkan supaya pembangunan dapat berjalan lancar yang pada akhirnya berdampak positif bagi masyarakat itu sendiri, baik pada skala lokal maupun nasional.

Berkaitan dengan hal diatas Widjaja (2013:95) mengemukakan bahwa "Pembangunan di desa memang sepatutnya lebih banyak ditentukan oleh masyarakat desa sendiri". Jika partisipasi masyarakat dalam pemilihan kepala desa
Semuntai Kecamatan Sepauk Kabupaten Sintang meningkat dengan sendirinya dapat membentuk kebersamaan dalam membangun khususnya di Desa Semuntai. Menanggapi permasalahan yang terurai di atas penulis merasa perlu melakukan penelitian yang berbentuk Studi Kasus dengan Judul "Tingkat Partisipasi Masyarakat dalam Pemilihan Kepala Desa Semuntai pada Tahun 2014 sebagai Implementasi Undang-undang Nomor 6 Tahun 2014".

\section{B. Metode}

Dalam penelitian ini penulis menggunakan pendekatan kualitatif deskriptif, dengan bentuk studi kasus. Teknik pengumpulan data berupa observasi langsung, wawancara, dan teknik dokumentasi. Alat pengumpulan data yang digunakan yaitu pedoman observasi, pedoman wawancara, dan pedoman dokumentasi. Sementara itu subjeknya masyarakat di Desa Semuntai Kecamatan Sepauk Kabupaten Sintang.

\section{Pembahasan Dan Hasil}

Berdasarkan hasil penelitian yang telah dilakukan tentang tingkat partisipasi masyarakat dalam pemilihan kepala Desa Semuntai terdapat hal-hal sebagai berikut : Data pemilih tetap berjumlah 1.256. Dusun Belungai dengan jumlah 325 pemilih $(25,9 \%)$. Dusun Tebedak berjumlah 292. Dusun Tapang 
berjumlah 261. Selanjutnya Dusun Mengkurai berjumlah 378.

Data Tingkat Partisipasi Politik Masyarakat dalam Pemilhan Kepala Desa Semuntai pada Tahun 2014

Hasil Rekapitulasi total Suara Pemilih Kepala Desa Semuntai pada tahun 2014 sebanyak 734 suara. Dusun Belungai berjumlah 190. Dusun Tebedak berjumlah 199. Dusun Tapang Tambit berjumlah 160. Dusun Mengkurai dengan jumlah 197.

Selanjutnya hasil rekapipulasi suara golput sebesar 522. Dusun Belungai berjumlah 135. Dusun Tebedak berjumlah 93. Dusun Tapang Tambit berjumlah 97. Dusun Mengkurai berjumlah 197.

Hasil perolehan suara dari keempat kandidat dapat dirinci seperti dibawah ini:

Ariyanto memperoleh suara 112. Jepri 236. Kemudian disusul Ripung dengan perolehan suara 132. Selanjutnya, Jono memperolehsuara sebanyak 254.

Upaya pemerintah desa untuk mendorong partisipasi masyarakat dalam pemilihan kepala Desa Semuntai

Adapun upaya yang dilakukan pemerintah Desa Semuntai guna mendorong partisipasi masyarakat, anatara lainmemberikan motivasi kepada seluruh warga supaya aktif dalam setiap kegiatan yang berhungan dengan politik, walaupun masih pada harapan kecil. Upaya lain yaitu selalu menjalin komunikasi dan interaksi yang baik dengan masyarakat.

Faktor-faktor pendukung dan penghambat partisipasi masyarakat dalam pemilihan Kepala Desa Semuntai

Faktor pendukung masyarakat untuk berpartisipasi dalam pemilihan Kepala Desa Semuntai pada tahun 2014 yaitu keinginan untuk menjadi desa yang mandiri, maju dan sejahtera. Sementara itu faktor penghambatnya yaitukurang maksimalnya sosialisasi politik terkait pemilihan kepala desa dari panitia pemilihan kepala desa, akses jalan yang jauh,serta masyarakat yang tidak bisa meninggalkan pekerjaannya.

\section{Simpulan}

Setelah melakukan penelitian dilapangan dengan mengunakan alat pengumpul data wawancara maka dapat disimpulkan bahwa tingkat partisipasi masyarakat dalam pemilihan Kepala Desa Semuntai masih rendah. Hal ini terlihat pada saat pilkades hanya sebagian masyarakat yang mau ikut berpartisispasi, masyarakat tidak mau berpartisipasi karena kecewa dengan janji-janji para calon kades yang tidak pernah ditepati. Faktor pendukung dalam pemilihan yaitu masyarakatkeinginan untuk menjadi desa yang mandiri, maju dan sejahtera, sedangkan yang menjadi 
faktor penghambatnya yaitu kurangnya kepercayaan masyarakat terhadap pemerintah desa karena tidak pernah konsisten dengan janjinya.

\section{Daftar Pustaka}

Aryani. D. M. 2014. "Studi Tentang Faktor-Faktor Penyebab Rendahnya Partisipasi Politik Masyarakat Dalam Pemilu Presiden. Journal. Kelurahan Baqa Kecamatan Samarinda Seberang Kota Samarinda. Volume 3, Nomor 2.

Kumolo, Tjahjo. 2015. Politik Hukum Pilkada Serentak. Jakarta :PT Mizan Publika.

Maulina. P. S. 2014. "Partisipasi Politik Masyarakat Dalam Pemilu Legislatif.

Dapil 2 Kecamatan Sungai Kunjang Kota Samarinda.
Juornal Administrasi Negara, Volume 3, Nomor 1.

Moleong. Lexy J. 2015. Metodologi Penelitian Kualitatif. Bandung. PT Remaja Rosdakarya.

Sugiyono,

2012.MetodePenelitianKuant itatifKualitatif Dan $R \& D$. Bandung: Alfabeta.

Taufik. Istiari. 2013. "Peran Pemuka Pendapat dalam Meningkatkan Partisipasi Pilkades di Desa Prangat Selatan tahun 2013. Juornal Ilmu Komunikasi, Volume 1, Nomor 4.

Undang-undang Nomor 15 tahun 2011 tentang penyelenggaraan pemilihan umum.

Undang-Undang Nomor 6 Tahun 2014 Tentang Desa.

Undang-Undang Nomor 23 Tahun 2014 Tentang Pemerintahan Daerah. 